\title{
MODELS OF CUSTOMER SATISFACTION WITH SUPERMARKETS IN POLAND
}

\author{
Grzegorz Biesok $^{1}$, Jolanta Wyród-Wróbel ${ }^{1}$
}

${ }^{1}$ University of Bielsko-Biala, Poland

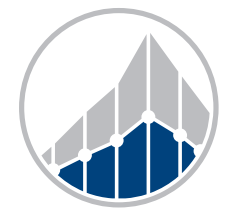

EUROPEAN JOURNAL OF BUSINESS SCIENCE AND TECHNOLOGY

Volume 4 Issue 1 ISSN 2336-6494 www.ejobsat.com

\begin{abstract}
The purpose of this paper was to compare three models of customer satisfaction with supermarkets in Poland. The authors decided to verify what kinds of satisfaction models are appropriate for describing relations between customer satisfaction and other constructs. The authors used structural equation modelling (SEM) to test and validate the models containing several latent variables, such as: perceived quality, perceived value and customer expectations. All of them were equipped with proper manifest variables, measured in a survey. The survey questionnaires were distributed using snowballing method. Verified models confirmed the significant impact of perceived quality on customer satisfaction and these two variables demonstrated the highest correlation. The study showed that the customer satisfaction reaches higher determination in more complicated models, such as value-based model and confirmation model. The study also showed that customer expectations don't have a direct impact on customer satisfaction.
\end{abstract}

\section{KEY WORDS}

consumer research, customer satisfaction, customer satisfaction model, supermarkets, structural equation modelling (SEM)

\section{JEL CODES}

M300, L810

\section{INTRODUCTION}

One of the most popular places for shopping basic goods is a supermarket. Supermarkets offer different types of goods e.g. food, cleaning products, all kinds of electronics and care products. Supermarkets introduce their own brands and they also introduce products that have the features of luxury products. Their prices are lower than the corresponding branded products (Maciejewski, 2016). They are cheaper but they have a connection with the original 
brand and support the atmosphere of closeness to luxury (Ochkovskaya, 2013).

Nowadays a consumer can choose of a large variety of supermarkets and switching a supplier is not a problem. Due to this, meeting the consumers' requirements and achieving their satisfaction should be fundamental goal for the supermarkets; because as claims Mohan (2013), improving customer satisfaction leads to improved business results of the firm in terms of sales and profitability.

As notice Pilelienè and Grigaliūnaitè (2013) there are a lot of results proving direct positive influence of customer satisfaction to increased economic benefits of the owners and other stakeholders of the organization.

Among the number of currently available approaches for studying customer satisfaction, very useful ones are satisfaction models. In the literature there are a lot of examples of customer satisfaction models i.e. classical concept as American Customer Satisfaction Index (ACSI), or as European Customer Satisfaction Index (ECSI), and propositions of models modified and supplemented e.g. additions of a new variables to them.

The purpose of this paper was to compare three models of customer satisfaction with supermarkets in Poland. The authors decided to verify which kind of the satisfaction model is appropriate for describing relations between customer satisfaction and other constructs. They chose to verify and compare three models of the satisfaction, i.e. the quality-based model, the value-based model and the confirmation model. These three types of the models are the basic types of customer satisfaction models (Biesok and Wyród-Wróbel, 2016).

The reason for taking up this study was to determine which type of customer satisfaction model is the most adequate to illustrate the satisfaction of supermarket customers. The existing literature does not resolve this issue, various authors use different models, among which standard models dominate, such as ECSI.

Such a resolution would be important because it would show a model, which would be the basis for developing satisfaction models in this specific branch. Potential outcomes of the study would allow to focusing on one of possible type of the models, which could be developed or adopted on different markets.

The study consists of five sections. Section 2 discusses the concepts of customer satisfaction with supermarkets and presents some factors regarding customer satisfaction with supermarkets. Section 3 is concerned with research methods used in this study and gives an overview of the survey. The next sections discuss the results and contributions of this research and limitations of the study.

\section{CUSTOMER SATISFACTION WITH SUPERMARKETS}

Customer satisfaction has an influence on marketing strategies of every company. Improving customer satisfaction leads to improved business results of the firm in terms of sales and profitability (Mohan, 2013; Angelova and Zekiri, 2011). Customer satisfaction is an important driver to customer loyalty and to the success of businesses; it is the consumers' fulfilment response (Oliver, 1997). Most frequently it is said that customer satisfaction depends on variables such as: consumer expectations (Fornell et al., 1996), quality of service and products
(Lee and Cunningham, 1996), price (Anderson et al., 1994), perceived value (Pawlasová and Klézl, 2017) and trust towards the brand and the company (Pawlasová, 2015).

Customer satisfaction in a retail setting has been linked to a number of important outcomes including sales performance, customer retention and loyalty (Weerasiri, 2015 for Darian et al., 2001). Satisfied consumers display loyalty and a higher repurchase rate, while loyal consumers display satisfaction and come back to repurchase the product (Catherine and Magesh, 
Tab. 1: Determinants of customer satisfaction with supermarkets

\begin{tabular}{|c|c|c|}
\hline Motivating factors & Excitement factors & Confirmation factors \\
\hline $\begin{array}{l}\text { - } \text { overall brand image } \\
\text { - } \text { service quality } \\
\text { variety and shopping } \\
\text { convenience } \\
\text { - } \text { services and physical } \\
\text { appearance } \\
\text { - reviews about the store } \\
\text { - marketing stimuli, } \\
\text { advertisement, availability } \\
\text { of parking space }\end{array}$ & $\begin{array}{l}\text { - } \text { store atmosphere } \\
\text { - } \text { stimulation of senses } \\
\text { - } \text { presentation of goods } \\
\text { - consumer relationship proneness } \\
\text { - trust and commitment } \\
\text { - personal interaction and convenience } \\
\text { product, procedures, the moments of } \\
\text { - } \text { offer of the retailer } \\
\text { - } \text { performance orvices and physical appearance }\end{array}$ & $\begin{array}{l}\text { - } \text { store loyalty } \\
\text { - product quality } \\
\text { - } \text { positive emotions, } \\
\text { - quality of communication } \\
\text { and company's image } \\
\text { - interfacing with a client } \\
\text { after the purchase } \\
\text { - perception of purchased } \\
\text { product's quality, } \\
\text { intention to repurchase }\end{array}$ \\
\hline
\end{tabular}

Notes: Authors' elaboration based on Theodoridis and Chatzipanagiotou (2009), Neupane (2015), Weerasiri (2015), Rana et al. (2014), Thương (2016), Babin and Darden (1996), Noyan and Simsek (2011), Bloemer and Odekerken-Schröder (2002), Morschett et al. (2005), Darian et al. (2001), and Biesok and Wyród-Wróbel (2011).

2017). Khan (2006) marks that the choice of place of purchase depends on perception, self concept, social and cultural background, age, family cycle, attitudes, beliefs, values, motivation, personality, social class and many other factors that can be either internal or external.

Stores offer their consumers tangible and intangible components of the services provided, they include the following: products and their packaging (Marx and Erasmus, 2006), the visual elements of physical store environment e.g. colours, displays, decorative features, ease of movement etc., stimulation of senses: smell, condition of the air, music, lighting, the various procedures which consumer have to follow e.g. cashiers, queues, traffic, trolleys, etc. (Theodoridis and Chatzipanagiotou, 2009), the moments of contact with the personnel and the core offer of the retailer i.e. product variety, assortment, quality and pricing policy (Morschett et al., 2005, cited in Theodoridis and Chatzipanagiotou, 2009), employees knowledge and behaviour, prompt service, individual attention, and complaint handling (Ushantha et al., 2014).

Components mentioned above have a different influence on customer satisfaction when talking about supermarkets. Stores with a favourable atmosphere are likely to increase the positive buying experience and customer satisfaction (Babin and Darden, 1996). Bloemer and Odekerken-Schröder (2002) show that significant influence on customer satisfaction have such factors as consumer relationship proneness, positive effect and image of the store. Also Neupane (2015) mentions that overall brand image has a positive effect on consumers satisfaction and their loyalty.

Among other factors that influence satisfaction with supermarkets there are: product, price (Thương, 2016; Huddleston et al., 2008), service quality (Weerasiri, 2015), personal interaction, convenience, services and physical appearances (Thương, 2016), sales personnel competence, convenience, reliability, physical evidence, after sales service and product innovation (Kumar, 2017). The studies don't confirm the influence of merchandising on customer satisfaction (Theodoridis and Chatzipanagiotou, 2009), however, perceived merchandise quality has a stronger impact on customer loyalty (Reddy et al., 2011).

Previous studies identified some factors regarding customer satisfaction with supermarkets. Tab. 1 presents a proposition of three types of variables which could influence customer satisfaction with supermarkets.

The list of actual or potential factors that may form the basis of model construction is not closed. Recent research indicates many interesting majors that should be taken in future studies. And so, for example, identify and investigate the factors and test models in different types of stores: for instance clothing stores 


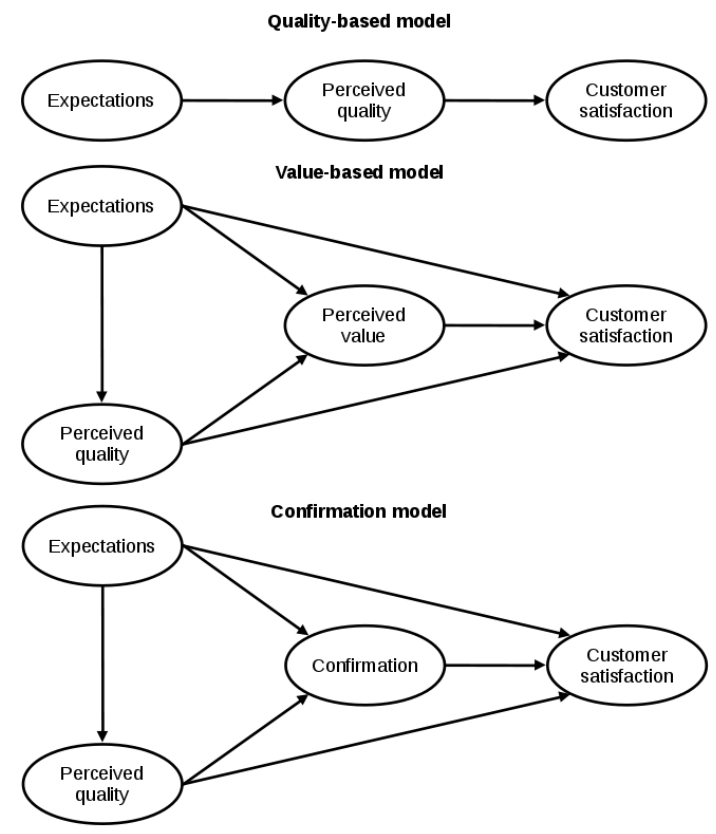

Fig. 1: Models used in the study

with technical goods (Terblanche, 2018; Grah and Tominc, 2015), investigate the relationship between satisfaction with the local assortment and actual store patronage (Clarke et al., 2012); the role of corporate image on customer satisfaction may be used as a moderating factor (Demirci Orel and Kara, 2014). These proposals show that the structures of satisfaction models are not closed but there is still a lot of space for them to develop and modify.

\section{METHODOLOGY AND DATA}

\subsection{Research Instruments}

In order to compare different approaches on customer satisfaction modelling the structural equation modelling (SEM) was used and three satisfaction models were proposed:

1. quality-based model - containing three latent variables: expectation (EXP), perceived quality (QUAL) and customer satisfaction (SAT),
2. value-based model - containing four latent variables: expectation (EXP), perceived quality (QUAL), perceived value (VAL) and customer satisfaction (SAT),

3. confirmation model - with four latent variables: expectation (EXP), perceived quality (QUAL), confirmation (CONF) and customer satisfaction (SAT).

All of them are shown in Fig. 1. 
Tab. 2: Variables used in the model

\begin{tabular}{|c|c|c|}
\hline $\begin{array}{l}\text { Latent } \\
\text { variable }\end{array}$ & Manifest variables & $\begin{array}{l}\text { Reliability } \\
\text { coefficients }\end{array}$ \\
\hline $\begin{array}{l}\text { Expectations } \\
\text { EXP }\end{array}$ & $\begin{array}{l}\text { I have big expectations regarding the quality of products in this supermarket. } \\
\text { I expect that in this supermarket I will always find products that I currently } \\
\text { need. } \\
\text { I have big expectations regarding the quality of customer service in this } \\
\text { supermarket. } \\
\text { I expect that the supermarket's personnel will always help me out. } \\
\text { I expect that the supermarket's personnel will react positively to my questions } \\
\text { and needs. }\end{array}$ & $\begin{array}{l}\alpha=0.844 \\
\rho=0.890\end{array}$ \\
\hline $\begin{array}{l}\text { Perceived } \\
\text { quality } \\
\text { QUAL }\end{array}$ & $\begin{array}{l}\text { The supermarket offers good quality products. } \\
\text { Products meet my requirements. } \\
\text { Customer service in the supermarket is very good. } \\
\text { I am being served according to my expectations. } \\
\text { The variety of products meets my demand. } \\
\text { The supermarket functions better than other supermarkets in the area. } \\
\text { The staff is reliable and professional. } \\
\text { I can always count on help from the personnel. }\end{array}$ & $\begin{array}{l}\alpha=0.898 \\
\rho=0.904\end{array}$ \\
\hline $\begin{array}{l}\text { Perceived } \\
\text { value } \\
\text { VAL }\end{array}$ & $\begin{array}{l}\text { Products bought in this supermarket are worth their price. } \\
\text { Prices in this supermarket are reasonable. } \\
\text { For the same amount of money I can buy more here, than at the competitor's. }\end{array}$ & $\begin{array}{l}\alpha=0.843 \\
\rho=0.906\end{array}$ \\
\hline Confirmation & $\begin{array}{l}\text { To sum up: the quality of products in this supermarket is better than I } \\
\text { expected. }\end{array}$ & $\alpha=0.774$ \\
\hline $\mathrm{CONF}$ & $\begin{array}{l}\text { The quality of service in this supermarket is better than I expected. } \\
\text { The prices of products are lower than I expected. }\end{array}$ & $\rho=0.869$ \\
\hline $\begin{array}{l}\text { Customer } \\
\text { satisfaction } \\
\text { SAT }\end{array}$ & $\begin{array}{l}\text { Overall, I am happy with the purchase in this supermarket. } \\
\text { The supermarket meets my demand. } \\
\text { The supermarket is close to ideal. }\end{array}$ & $\begin{array}{l}\alpha=0.853 \\
\rho=0.913\end{array}$ \\
\hline
\end{tabular}

Tab. 3: Structure of the sample concerning respondents

\begin{tabular}{llr}
\hline Feature & & Percent \\
\hline Gender & Female & $74.0 \%$ \\
& Male & $26.0 \%$ \\
\hline Age & no data & $2.0 \%$ \\
& less than 18 & $1.0 \%$ \\
& $18-25$ & $36.0 \%$ \\
& $25-40$ & $31.0 \%$ \\
& $40-65$ & $27.0 \%$ \\
\hline Region & more than 65 & $3.0 \%$ \\
\hline Running a household & Lesser Poland Voivodeship & $12.0 \%$ \\
& Silesian Voivodeship & $88.0 \%$ \\
\hline Average spending on shopping in a supermarket & No & $37.0 \%$ \\
& Yes & $63.0 \%$ \\
\hline
\end{tabular}


The authors used 5 constructs in total, and assumed that all of them shape in a reflective way. Every latent variable was equipped with a set of manifest variables. The set of manifest variables was used in order to measure them. Scales are self-developed, only manifest variables of customer satisfaction (SAT) were adopted form Pilelienè and Grigaliūnaitè (2013). At first, the authors proposed more variables in the measurement model, but having collected survey data, preliminary verification of them was performed and variables aggravating the internal consistency of the measurement model were eliminated. For this verification the Cronbach's $\alpha$ coefficient and Dillon-Goldstein (D. G.) $\rho$ coefficient were used. Final sets of the variables used in the measurement model are shown in Tab. 2.

Manifest variables were measured with 5point Likert's scale, from 1 - "I do not agree at all" to 5 - "I extremely agree". There were no reverse-scaled items.

\subsection{The Sampling Method}

Manifest variables were measured in a survey. The survey questionnaire was created by the authors. The questionnaire consisted of two parts:

1. The first one described the profile of the customer: gender, age, place of residence, running of a household (yes or no), frequency of shopping in supermarkets and average amount of money for a single purchase,

2. The second part allowed to assess a chosen supermarket in questions concerning: the supermarkets name, location, frequency of shopping in it and 35 statements describing manifest variables. Every respondent had a possibility to assess 1-3 supermarkets.

The questionnaires were distributed in southern Poland (Silesian and Lesser Poland Voivodeships, Poland), using snowballing method. In return 215 filled questionnaires were obtained. Tab. 3 and 4 show the structure of the sample.
Tab. 4: Structure of the sample regarding supermarkets

\begin{tabular}{|c|c|}
\hline Feature & Percent \\
\hline \multicolumn{2}{|l|}{ Location of the supermarket } \\
\hline Silesian Voivodeship districts: & $93.0 \%$ \\
\hline - Bielsko-Biała & $30.2 \%$ \\
\hline - bielski & $11.6 \%$ \\
\hline - cieszyński & $10.2 \%$ \\
\hline - pszczyński & $1.4 \%$ \\
\hline - Tychy & $2.3 \%$ \\
\hline - żywiecki & $37.2 \%$ \\
\hline Lesser Poland Voivodeship districts: & $7.0 \%$ \\
\hline - Kraków & $1.4 \%$ \\
\hline - oświęcimski & $3.3 \%$ \\
\hline - wadowicki & $2.3 \%$ \\
\hline \multicolumn{2}{|l|}{ Brand of the supermarket } \\
\hline - Biedronka & $33.5 \%$ \\
\hline - Lidl & $19.1 \%$ \\
\hline - Kaufland & $8.4 \%$ \\
\hline - Tesco & $7.0 \%$ \\
\hline - Lewiatan & $5.1 \%$ \\
\hline- Dino & $4.2 \%$ \\
\hline - Delikatesy Centrum & $4.2 \%$ \\
\hline - Intermarché & $3.3 \%$ \\
\hline- Aldi & $2.8 \%$ \\
\hline - Netto & $1.9 \%$ \\
\hline - other & $10.7 \%$ \\
\hline
\end{tabular}

\subsection{Data Analysis}

The authors used in the study a software dedicated to structural equation modelling (SEM), using partial least square methods (PLS). Confidence intervals and levels of significance were calculated using bootstrap methods. The authors did not accept questionnaires with missing data and they removed them. All regressions in the inner model were calculated with intercepts (with intercepts different than $0)$. Latent variable scores were estimated in the manifest variables scale (so without transformation). 
Tab. 5: Quality-based model - evaluation of the measurement model

\begin{tabular}{lcccccc}
\hline Latent variable & Type & Items & Cronbach's $\alpha$ & D. G. $\rho$ & 1st EV & 2nd EV \\
\hline Expectations (EXP) & Exogenous Reflective & 5 & 0.844 & 0.890 & 3.088 & 0.854 \\
Perceived quality (QUAL) & Endogenous Reflective & 8 & 0.878 & 0.904 & 4.340 & 1.210 \\
Customer satisfaction (SAT) & Endogenous Reflective & 3 & 0.857 & 0.913 & 2.334 & 0.426 \\
\hline
\end{tabular}

Note: EV - eigenvalue

Tab. 6: Quality-based model - paths in inner model

\begin{tabular}{lccccc}
\hline Path & Path coefficient & Standard error & $t$ & $p>|t|$ & Significance \\
\hline EXP $\rightarrow$ QUAL & 0.537 & 0.044 & 12.314 & 0.000 & Yes $p<0.001$ \\
QUAL $\rightarrow$ SAT & 0.964 & 0.059 & 16.218 & 0.000 & Yes $p<0.001$ \\
\hline
\end{tabular}

Tab. 7: Quality-based model - modelling results

\begin{tabular}{lccccc}
\hline Endogenous LV & Equation of the model & $R^{2}$ & $F$ & $p>F$ & Significance \\
\hline QUAL & $=1.607+0.537 \mathrm{EXP}$ & 0.426 & 151.625 & 0.000 & Yes $p<0.001$ \\
SAT & $=-0.095+0.964 \mathrm{QUAL}$ & 0.563 & 263.024 & 0.000 & Yes $p<0.001$ \\
\hline
\end{tabular}

Tab. 8: Value-based model - evaluation of the measurement model

\begin{tabular}{lcccccc}
\hline Latent variable & \multicolumn{1}{c}{ Type } & Items & Cronbach's $\alpha$ & D. G. $\rho$ & 1st EV & 2nd EV \\
\hline Expectations (EXP) & Exogenous Reflective & 5 & 0.835 & 0.883 & 3.017 & 0.887 \\
Perceived quality (QUAL) & Endogenous Reflective & 8 & 0.872 & 0.900 & 4.249 & 1.254 \\
Perceived value (VAL) & Endogenous Reflective & 3 & 0.843 & 0.906 & 2.289 & 0.488 \\
Customer satisfaction (SAT) & Endogenous Reflective & 3 & 0.853 & 0.911 & 2.322 & 0.435 \\
\hline
\end{tabular}

Tab. 9: Value-based model - paths in inner model

\begin{tabular}{lccccc}
\hline Path & Path coefficient & Standard error & $t$ & $p>|t|$ & Significance \\
\hline $\mathrm{EXP} \rightarrow$ QUAL & 0.528 & 0.044 & 11.982 & 0.000 & Yes $p<0.001$ \\
$\mathrm{EXP} \rightarrow$ VAL & -0.037 & 0.089 & -0.419 & 0.676 & No \\
$\mathrm{QUAL} \rightarrow$ VAL & 0.544 & 0.109 & 5.001 & 0.000 & Yes $p<0.001$ \\
$\mathrm{EXP} \rightarrow$ SAT & -0.016 & 0.057 & -0.274 & 0.785 & No \\
$\mathrm{QUAL} \rightarrow$ SAT & 0.806 & 0.074 & 10.913 & 0.000 & Yes $p<0.001$ \\
$\mathrm{VAL} \rightarrow$ SAT & 0.350 & 0.045 & 7.766 & 0.000 & Yes $p<0.001$ \\
\hline
\end{tabular}

Tab. 10: Value-based model - modelling results

\begin{tabular}{lcrrrc}
\hline Endogenous LV & Equation of the model & $R^{2}$ & $F$ & $p>F$ & Significance \\
\hline QUAL & $=1.650+0.528 \mathrm{EXP}$ & 0.414 & 143.578 & 0.000 & Yes $p<0.001$ \\
VAL & $=1.728-0.037 \mathrm{EXP}+0.544 \mathrm{QUAL}$ & 0.160 & 19.200 & 0.000 & Yes $p<0.001$ \\
SAT & $=-0.710-0.016 \mathrm{EXP}+0.806 \mathrm{QUAL}+0.350 \mathrm{VAL}$ & 0.662 & 131.391 & 0.000 & Yes $p<0.001$ \\
\hline
\end{tabular}




\section{RESULTS}

\subsection{Quality-Based Model}

Building this model the authors had to exclude 9 questionnaires because of missing data, so the final sample of 206 units was used. Tab. 5 shows that measurement model was properly structured: Cronbach's alpha and Dillon-Goldstein's rho significantly exceeded their threshold values (0.7) and the first eigenvalues were bigger than 1.000 (cf. Biesok and Wyród-Wróbel, 2016). The evaluation of the measurement model gave positive results, and this set of variables can be used to determine the internal structure of the model. Tab. 6-7 present the results of the modelling.

\subsection{Value-Based Model}

In this case the authors excluded 10 questionnaires because of missing data. As in the previous case, the measurement model showed an adequate internal consistency (Tab. 8). Tab. 9 and 10 present results of the modelling.

\subsection{Confirmation Model}

The last model was determined on the basis of 206 units sample, 9 questionnaires were excluded because of missing data. In this case the measurement model was positively evaluated as well. Tab. 11-13 present results of the modelling.

\subsection{Comparison of the Results}

In all three cases the model fit is satisfactory. Goodness of Fit (GoF) index calculated for outer and inner model exceeds threshold value 0.9 (Biesok and Wyród-Wróbel, 2016). Qualitybased model determines customer satisfaction in the lowest degree: coefficient of determination reaches the value 0.563 , which means that $44 \%$ of customer satisfaction variance is not explained by the model. Last two models have better determination, respectively 0.662 and 0.650. According to Sanchez (2013) it is very high and desirable level of determination.

Standardized path of the coefficients demonstrates that perceived quality has the biggest contribution to the customer satisfaction. Interestingly, in the value-based and confirmation model the impact of expectations on customer satisfaction is statistically insignificant. Tab. 14 shows comparison of tested models and Fig. 2 their graphical interpretation.

\section{DISCUSSION AND CONCLUSIONS}

In general, the results show that none of the presented model concepts can be categorically rejected.

Each model confirmed the significant impact of perceived quality on customer satisfaction, and this conforms to the results obtained in the previous studies. Perceived quality and customer satisfaction demonstrated the highest correlation and the quality-based model shows that perceived quality determines satisfaction in about $56 \%\left(R^{2}=0.5625\right)$.

The earlier researches also identified that high service quality leads to high customer satisfaction (Taylor and Baker, 1994; Fornell et al., 1996); and in the case of supermarkets similar strong positive relationship between service quality offered by supermarkets in Sri Lanka and the customer satisfaction was shown e.g. by Weerasiri (2015) or Ushantha et al. (2014). Ushantha et al. (2014) showed that both product quality and service quality are for consumers equally major factors for consideration in deciding the overall service quality of a supermarket.

Perceived quality is an important factor creating customer satisfaction, but it is not sufficient. The customer satisfaction reaches a higher determination in more complicated models: value-based model and confirmation model. 
Tab. 11: Confirmation model - evaluation of the measurement model

\begin{tabular}{lcccccc}
\hline Latent variable & \multicolumn{1}{c}{ Type } & Items & Cronbach's $\alpha$ & D. G. $\rho$ & 1st EV & 2nd EV \\
\hline Expectations (EXP) & Exogenous Reflective & 5 & 0.844 & 0.890 & 3.088 & 0.854 \\
Perceived quality (QUAL) & Endogenous Reflective & 8 & 0.878 & 0.904 & 4.340 & 1.210 \\
Confirmation (CONF) & Endogenous Reflective & 3 & 0.774 & 0.869 & 2.066 & 0.509 \\
Customer satisfaction (SAT) & Endogenous Reflective & 3 & 0.857 & 0.913 & 2.334 & 0.426 \\
\hline
\end{tabular}

Tab. 12: Confirmation model - paths in inner model

\begin{tabular}{lccccc}
\hline Path & Path coefficient & Standard error & $t$ & $p>|t|$ & Significance \\
\hline $\mathrm{EXP} \rightarrow$ QUAL & 0.536 & 0.043 & 12.332 & 0.000 & Yes $p<0.001$ \\
$\mathrm{EXP} \rightarrow$ CONF & 0.160 & 0.072 & 2.239 & 0.026 & Yes $p<0.05$ \\
$\mathrm{QUAL} \rightarrow$ CONF & 0.584 & 0.087 & 6.697 & 0.000 & Yes $p<0.001$ \\
$\mathrm{EXP} \rightarrow$ SAT & -0.084 & 0.059 & -1.436 & 0.152 & No \\
$\mathrm{QUAL} \rightarrow$ SAT & 0.743 & 0.078 & 9.504 & 0.000 & Yes $p<0.001$ \\
$\mathrm{CONF} \rightarrow$ SAT & 0.406 & 0.057 & 7.141 & 0.000 & Yes $p<0.001$ \\
\hline
\end{tabular}

Tab. 13: Confirmation model - modelling results

\begin{tabular}{lcrrrc}
\hline Endogenous LV & Equation of the model & $R^{2}$ & $F$ & $p>F$ & Significance \\
\hline QUAL & $=1.611+0.536 \mathrm{EXP}$ & 0.427 & 152.071 & 0.000 & Yes $p<0.001$ \\
CONF & $=0.457+0.160 \mathrm{EXP}+0.584 \mathrm{QUAL}$ & 0.374 & 60.617 & 0.000 & Yes $p<0.001$ \\
SAT & $=-0.277-0.084 \mathrm{EXP}+0.743$ QUAL $+0.406 \mathrm{CONF}$ & 0.650 & 125.289 & 0.000 & Yes $p<0.001$ \\
\hline
\end{tabular}

Tab. 14: Comparison of the models

\begin{tabular}{lccc}
\hline Feature of the model & Quality-based model & Value-based model & Confirmation model \\
\hline Goodness of Fit (relative) & 0.921 & 0.856 & 0.903 \\
Goodness of Fit - outer model & 0.995 & 0.994 & 0.995 \\
Goodness of Fit - inner model & 0.926 & 0.861 & 0.908 \\
Determination of customer satisfaction $\left(R^{2}\right)$ & 0.563 & 0.662 & 0.650 \\
\hline Impact on customer satisfaction: & & & -0.075 \\
Expectations & & -0.010 & $(0.476)$ \\
& & $(0.461)$ & $\mathrm{n} . \mathrm{s}$. \\
Perceived quality & 0.750 & 0.610 & 0.574 \\
& $(0.750)$ & $(0.747)$ & $(0.749)$ \\
Perceived value & $p<0.001$ & $p<0.001$ & 0.001 \\
& & 0.347 & $(0.596)$ \\
Confirmation & & $p<0.001$ & $(0.680)$ \\
& & & 0.001 \\
\hline
\end{tabular}

Note: n. s. - not significant 


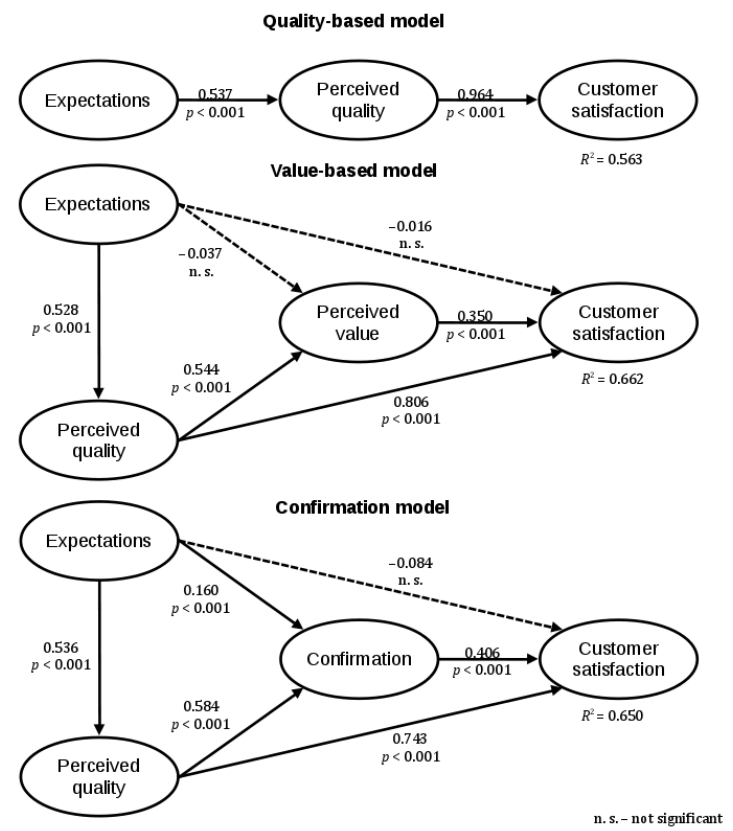

Fig. 2: Models determined in the study

The main contribution of the study is a finding that value based model is an appropriate concept for studying and modelling the customer satisfaction with supermarkets. However, in the implemented model the perceived value has very low and unacceptable determination $\left(R^{2}=0.160\right)$. This means that the source of its variance is not sufficiently explained by the model and it is necessary to enrich this model with other factors that may affect the perceived value. Various studies try to find other antecedents of perceived value, e.g. experience quality (Chen and Chen, 2010), sacrifice (Cronin et al., 2000).

This study did not show that customer expectations have a direct impact on customer satisfaction. Other authors got similar results in their research. Pilelienè and Grigaliūnaitè (2013) in their study with supermarkets in Lithuania showed that customer expectations have direct effects on perceived value and customer satisfaction, but the influence on customer satisfaction is less statistically significant. On the other hand, Yi and La (2003) demonstrated that the impact of expectations on the satisfaction is statistically insignificant.
Relatively small sample is the main limitation of this study. Therefore, the results are treated as preliminary ones, and this research will be further developed. The sample is also limited territorially to the southern Poland and its structure is random because of chosen sampling technique - snowballing. The snowballing gives a possibility to reach many respondents, but loses control of the process of data obtaining. However, the acquired sample mirrors the structure of retail brands in Poland.

The second limitation is a low determination of perceived value and perceived quality constructs. It means that analysed models should be complemented with other latent variables.

Future studies will require a larger sample and more variables in the inner model. First of all, the value-based model should be supplemented with elements determining the perceived value. For example Gallarza and Saura (2006) proposed 8 factors affecting the value: efficiency, service quality, social value, play, aesthetics, perceived monetary cost, perceived risk and time and effort spent. Some of them may be used in building and verifying future models. 
Other variables that can be considered are: image, trust and emotions. For example, Burns and Neisner (2006) combine customer satisfaction with perceived quality and emotions. In their opinion if a performance is deemed as negative, not only the negative performance will affect level of satisfaction, but also the negative emotions associated with poor performance will most likely affect the level of satisfaction.
The second interesting area of the research is the impact of expectations on satisfaction. The question: "Why do some studies show that this influence is important and some do not?" is still waiting to be answered. It is necessary to know what factors affect this influence, and in what conditions does this influence grow.

\section{REFERENCES}

Anderson, E. W., Fornell, C. and Lehmann, D. R. 1994. Customer Satisfaction, Market Share, and Profitability: Findings from Sweden. Journal of Marketing, 58 (3), 53-66.

Angelova, B. and ZeKiRI, J. 2011. Measuring Customer Satisfaction with Service Quality using American Customer Satisfaction Model (ACSI Model). International Journal of Academic Research in Business and Social Sciences, 1 (3), 232-258.

Babin, B. J. and Darden, W. R. 1996. Good and Bad Shopping Vibes: Spending and Patronage Satisfaction. Journal of Business Research, 35 (3), 201-206.

Biesok, G. and Wyród-WróBel, J. 2016. Modele satysfakcji klienta. Warszawa: Difin.

Biesok, G. and Wyród-Wróbel, J. 2011. Pojęcie satysfakcji. Problemy jakości, 43 (1), 27-32.

Bloemer, J. M. M. and Odekerken-Schröder, G. J. 2002. Store Satisfaction and Store Loyalty Explained by Customer- and Store-Related Factors. Journal of Consumer Satisfaction, Dissatisfaction and Complaining Behavior, 15, 68-80.

Burns, D. J. and NeISNer, L. 2006. Customer Satisfaction in a Retail Setting: The Contribution of Emotion. International Journal of Retail $\&$ Distribution Management, 34 (1), 49-66.

Catherine, S. and Magesh, R. 2017. Retail Shopper's Satisfaction using Differentiation Strategies. Indian Journal of Scientific Research, 14 (1), 74-76.

Chen, C.-F. and Chen, F.-S. 2010. Experience Quality, Perceived Value, Satisfaction and Behavioral Intentions for Heritage Tourists. Tourism Management, 31 (1), 29-35.

Clarke, I., Oppewal, H. and Kirkup, M. 2012. Consumer Satisfaction with Local Retail Diversity in the UK: Effects of Supermarket Access, Brand Variety, and Social Deprivation. Environment and Planning A, 44 (8), 1896-1911.
Cronin, J. J., Brady, M. K. and Hult, G. T. M. 2000. Assessing the Effects of Quality, Value, and Customer Satisfaction on Consumer Behavioral Intentions in Service Environments. Journal of Retailing, 76 (2), 193-218.

Darian, J. C., Tucci, L. A. and Wiman, A. R. 2001. Perceived Salesperson Service Attributes and Retail Patronage Intentions. International Journal of Retail \& Distribution Management, 29 (5), 205-213.

Demirci Orel, F. and Kara, A. 2014. Supermarket Self-checkout Service Quality, Customer Satisfaction, and Loyalty: Empirical Evidence from an Emerging Market. Journal of Retailing and Consumer Services, 21 (2), 118-129.

Fornell, C., Johnson, M. D., Anderson, E. W., ChA, J. and Bryant, B. E. 1996. The American Customer Satisfaction Index: Nature, Purpose and Findings. Journal of Marketing, 60 (4), 7-18.

Gallarza, M. G. and Saura, I. G. 2006. Value Dimensions, Perceived Value, Satisfaction and Loyalty: An Investigation of University Students' Travel Behaviour. Tourism Management, 27 (3), 437-452.

Grah, M. and Tominc, P. 2015. Relationships Among Store Image and Store Loyalty in Slovenia. Naše gospodarstvo/Our Economy, 61 (6), 28-37.

Huddleston, P., Whipple, J., Mattick, R. N. and LEE, S. J. 2008. Customer Satisfaction in Food Retailing: Comparing Specialty and Conventional Grocery Stores. International Journal of Retail 8 Distribution Management, 37 (1): 63-80.

Khan, M. 2006. Consumer Behaviour and Advertising Management. New Delhi: New Age International.

Kumar, P. 2017. An Examination of the Antecedents of Customer Satisfaction, Behavioral Response and Intentions Among Retail Store Formats. International Journal of Research - Granthaalayah, 5 (1), 239-257. 
Lee, M. and Cunningham, L. F. 1996. Customer Loyalty in the Airline Industry. Transportation Quarterly, 50 (2), 57-72.

Maciejewski, G. 2016. Preferencje konsumentów dotyczące wyboru miejsc zakupu towarów i usług konsumpcyjnych. Studia Ekonomiczne: Zeszyty Naukowe Uniwersytetu Ekonomicznego w Katowicach, 302, 7-17.

Marx, N. J. M. M and Erasmus, A. C. 2006. Customer Satisfaction with Customer Service and Service Quality in Supermarkets in a Third World Context. In Lees, M. C., Davis, T. and Gregory, D. (eds.) Asia-Pacific Advances in Consumer Research, Vol. 7, pp. 77-85.

Mohan, R. 2013. To Identify the Factors Impacting Customer Satisfaction in Food Retail Supermarkets. International Journal of Research and Development - A Management Review, 2 (2), 51-54.

Morschett, D., Swoboda, B. and Foscht, T. 2005. Perception of Store Attributes and Overall Attitude Towards Grocery Retailers: The Role of Shopping Motives. International Review of Retail, Distribution and Consumer Research, 15 (4), 423-447.

Neupane, R. 2015. The Effects of Brand Image on Customer Satisfaction and Loyalty Intention in Retail Supermarket Chain UK. International Journal of Social Sciences and Management, 2 (1), 9-26.

Noyan, F. and Simsek, G. G. 2011. Structural Determinants of Customer Satisfaction in Loyalty Models: Turkish Retail Supermarkets. Procedia Social and Behavioral Sciences, 30, 2134-2138.

Ochkovskaya, M. 2013. The Specific of Brand Building for Men in Fashion Luxury Industry. In Changes in Social and Business Environment, pp. 105-111.

Oliver, R. L. 1997. Satisfaction: A Behavioural Perspective on the Consumer New York, NY: McGraw-Hill.

Pawlasová, P. 2015. Comparison of Factors Affecting Users Satisfaction with Online Group Buying. In KAŠTAN, M. (ed.). MEKON 2015, pp. 299-313.

Pawlasová, P. and KlÉzL, V. 2017. Factors Affecting Generation Y Customer Satisfaction with Online Group-buying Purchases in South Korea. Acta Universitatis Agriculturae et Silviculturae Mendelianae Brunensis, 65 (6), 2045-2054.
Pileliené, L. and Grigaliūnaité, V. 2013.

Determination of customer satisfaction with supermarkets in Lithuania. Management of Organizations: Systematic Research (Organizaciju Vadyba: Sisteminiai Tyrmai), 66, 99-114.

Reddy, N. R. V. R., Reddy, T. N. and Azeem, B. A. 2011. Influence of Store Satisfaction, Merchandise Quality, and Service Quality on Store Loyalty. International Journal of Trade, Economics and Finance, 2 (5), 351-355.

SAnchez, G. 2013. PLS Path Modeling with R. [online]. Available at: http://www.gastonsanchez.com/ PLS_Path_Modeling_with_R.pdf. [Accessed 2018, February 24].

Rana, S. M. S., Osman, A. and Islam, M. A. 2014. Customer Satisfaction of Retail Chain Stores: Evidence from Bangladesh. Journal of Asian Scientific Research, 4 (10), 574-584.

TAYlor, S. A. and BAker, T. L. 1994. An Assessment of the Relationship Between Service Quality and Customer Satisfaction in the Formation of Consumers' Purchase Intentions. Journal of Retailing, 70 (2), 163-178.

Terblanche, N. S. 2018. Revisiting the Supermarket In-store Customer Shopping Experience. Journal of Retailing and Consumer Services, 40, 48-59.

Theodoridis, P. K., Chatzipanagiotou, K. C. 2009. Store Image Attributes and Customer Satisfaction Across Different Customer Profiles within the Supermarket Sector in Greece. European Journal of Marketing, 43 (5/6), 708-734.

Thương, N. T. T. 2016. Factors Influencing Customer Satisfaction Towards Supermarkets in Thai Nguyen City, Vietnam. International Journal of Economics, Commerce and Management. 4 (2), 464-474.

Ushantha, C., Wijeratne, A. and Achchuthan, S. 2014. An Assessment of Retail Service Quality: An Empirical Study of the RSQS in Sri Lankan Supermarkets. Developing Country Studies, 4 (3), 78-90.

Weerasiri, R. A. S. 2015. A Study on Service Quality and Customer Satisfaction of Supermarkets in Sri Lanka. Sri Lanka Journal of Marketing, 1 (2), 36-46.

YI, Y. and LA, S. 2003. The Moderating Role of Confidence in Expectations and the Asymmetric Influence of Disconfirmation on Customer Satisfaction. The Service Industries Journal, 23 (5), 20-47.

\section{AUTHOR'S ADDRESS}

Grzegorz Biesok, Department of Management, Faculty of Management and Transport, University of Bielsko-Biała, Willowa 2, 43-309 Bielsko-Biała, Poland, e-mail: gbiesok@ath.eu

Jolanta Wyród-Wróbel, Department of Management, Faculty of Management and Transport, University of Bielsko-Biała, Willowa 2, 43-309 Bielsko-Biała, Poland, e-mail: jwyrod@ath.eu 